\title{
Dose Managerial Optimism Affect Bank Risk-Taking? An Empirical Analysis Based on A-Share Listed Banks in China
}

\author{
Xiaomeng Lin \\ School of Economics, Jinan University, Guangzhou, China \\ Email: lxmfx21@hotmail.com
}

How to cite this paper: Lin, X.M. (2019) Dose Managerial Optimism Affect Bank Risk-Taking? An Empirical Analysis Based on A-Share Listed Banks in China. American Journal of Industrial and Business Management, 9, 503-511.

https://doi.org/10.4236/ajibm.2019.93034

Received: February 22, 2019

Accepted: March 15, 2019

Published: March 18, 2019

Copyright $\odot 2019$ by author(s) and Scientific Research Publishing Inc. This work is licensed under the Creative Commons Attribution International License (CC BY 4.0). http://creativecommons.org/licenses/by/4.0/

\begin{abstract}
In order to study the impact of management optimism on commercial banks' risk-taking, this paper uses the unbalanced panel data of 28 A-share listed banks in China to analysis. The empirical results of the OLS estimation show that the excessive optimism of management has a significant positive impact on the risk-taking of commercial banks. The bank's risk-taking level is also positively related to its deposit-loan ration and cost-income ratio, and has negative correlation with core capital adequacy and asserting scale. Therefore, when formulating policies, the supervisory authority should take into account the possible impact of managerial optimism on bank risk-taking. Commercial banks themselves should also pay attention to the excessive optimism of management in the design of compensation incentive system.
\end{abstract}

\section{Keywords}

Managerial Optimism, Commercial Bank, Risk-Taking

\section{Introduction}

Banks are the main pillar of China's financial system. The risk-taking of commercial banks not only affects its own operating performance, but also has a great impact on the stability of the entire financial and economic system. As the strategy maker and executor of commercial banks, management will undoubtedly affect the risk-taking level of commercial banks.

The issue of bank risk-taking is a hot topic in current academic research. A large number of studies have shown that bank risk-taking is affected by multiple factors such as external macro environment, market structure, and micro-silver enterprise characteristics. At the micro level, management is one of the impor- 
tant factors influencing bank risk-taking. The heterogeneity of the management's gender, age, education and other backgrounds, executive compensation, management power, etc. is all empirically proven to have an impact on bank risk exposure.

Also, with the development of psychology, a large number of literatures point out that people are optimistic about the uncertain future. Managers are corporate risk decisions who directly formulate the policy, their attitude towards uncertainty will inevitably impact on corporate risk-taking.

However, as China's banking industry continues to deepen reforms, by strengthening corporate governance to improve its own profit efficiency, management's role in bank management is more prominent. In the context of the complexity of the global economic environment and the entry of the domestic economy into a new normal, the banking industry has entered a low return with a high-risk development stage.

In this context, this paper analyzes the relationship between the excessive optimism of the management of China's listed banks and the level of risk-taking, and explores whether management's excessive optimism will have a positive and significant impact on the bank's risk-taking level. The results of the study are of great significance for commercial banks to improve internal governance, design compensation incentives. Also the result of this paper can be used to improve the government's regulatory system on bank.

\section{Theoretical Analysis and Hypothesis}

\subsection{Managerial Factors on Bank Risk-Taking}

At present, the academic community analyzes the risk-taking behavior of banks, mainly from the four perspectives, like market structure, capital supervision, macroeconomic factors and internal governance. There are a lot of literatures on how internal governance affects bank risk behavior. Gorton and Rosen (1995) [1] first proposed that managers as the controllers of the company and were the direct decision makers of risk-taking, but management was limited by information asymmetry and high supervision costs (Anderson and Fraser, 2000 [2]). There is a difference in the views of how managers' salaries affect the level of bank risk-taking. The research of Zhuang Yu, Zhu Jing and Sun Yanan (2013) [3] shows that the higher the salary of manager, the smaller the risk-taking of banks. But Xu Xin and Cheng Chunlin (2016) [4] believes that the salary incentives of bank managers are positively related to bank risks. Bao Huiling's (2018) [5] study shows that the heterogeneity of management in terms of gender, age, professional experience, and education level will all affect the bank's risk-taking level.

\subsection{Managerial Optimistic and Risk-Taking}

Kim, Jeong-Bon, Wang, Zheng, Zhang, Liandong (2014) [6] find that firms with overconfident CEOs have higher stock price crash risk than firms with 
non-overconfident CEOs. Tim R. Adam, Chitru S. Fernando, Evgenia Golubeva (2015) [7] found that managerial overconfidence, which has been found to influence a number of corporate decisions, also affects corporate risk management decisions.

Specifically for banks, Wang Wei (2005) [8] found that overconfidence can lead managers to favor more investment in more volatile projects, especially during the financial crisis. Bank managers' overconfidence behavior will increase bank risk, and for the larger scale banks, correlation between managerial overconfidence and bank risk are more positive. Xu Jia's (2018) [9] study shows that the higher the optimism of bank managers, the smaller the negative impact of investor sentiment on bank risk exposure. The empirical evidence of Wang Xiaoxu, Zhang Cheng and Zhao Lijiang (2015) [10] also shows that there is a stable quantitative relationship between managerial optimism and risk-taking levels.

\subsection{Literature Review}

Through the above combing, it can be seen that the management has an important impact on the level of risk-taking of the enterprise. For the bank is the same. Some scholars have studied the impact of management's overconfidence on bank-taking. Scholars in China already have paid attention to the impact of managerial over-optimism on the risk-taking of non-listed banks, but there are few studies related to listed banks in China. The overall volume of listed banks accounts for a large proportion of the Chinese banking industry. And the listed banks are subject to stricter supervision. Whether these banks have excessive management optimism leads to an increase in the level of bank risk-taking, which is the significance of this article.

According to the combing of the literature, the paper puts forward the hypothesis

$\mathrm{H}_{0}$ : the higher the level of optimism of managers, the higher the level of risk-taking of enterprises. The more optimistic managers tend to underestimate risks and overestimate the benefits.

\section{Empirical Research}

\subsection{Sample and Data Source}

The sample for this article is 29 commercial banks that have been listed on the A-share market, and the research period is from 2006 to 2017. The data sources are the wind database, the annual bank reports and the National Bureau of Statistics. Excluding those with unsound data, a total of 201 samples from 28 banks were obtained.

The choice of data is primarily due consideration of availability, reliability and integrity. The sample of this paper includes five state-owned banks, seven national joint-stock banks and 16 city commercial banks and rural commercial banks. The deposits and loans of these banks are more than $70 \%$ of the bank in 
China. So the samples are representative.

\subsection{Research Design}

In order to test the research hypothesis $\mathrm{H}_{0}$ and analyze the impact of manager optimism on bank risk-taking, this paper establishes the following measurement model:

$$
\operatorname{Risk}_{i t}=\beta_{0}+\beta_{1} O p_{i t}+\gamma \operatorname{Control}_{i t}+\varepsilon_{i t}
$$

Risk $_{i t}$ represents the bank's risk-taking. This paper chooses bankruptcy risk as a proxy variable. At present, the agent variables of bank-taking mainly include expected default rate, non-performing loan ratio, bankruptcy risk Z-score and risk-weighted assets as a percentage of total assets. Among them, the data of the expected default rate is poorly available. The calculation of non-performing loan ratio has great subjectivity and operability. And the non-performing loan ratio can not accurately reflect the bank's risk exposure. At the same time, with the continuous expansion of the bank's intermediary business and off-balance-sheet business, only considering the risk of the loan business cannot fully reflect the overall risk exposure of the bank. The $\mathrm{Z}$ Index is a comprehensive measure of a bank's profitability, leverage ratio and earnings volatility. And related financial data is easier to collect. Therefore, this paper chooses to use the $Z$ index as a proxy variable for bank risk-taking in the empirical study.

The formula for calculating the $Z$ index is as follows:

$$
Z_{i t}=\frac{R O A_{i t}+(E / A)_{i t}}{\left(\sigma_{R O A}\right)_{i t}}
$$

OP represents manager optimism. For manager optimism and overconfidence, the existing measurement methods include the continuous increase of management shareholding, the growth rate of total bank loans and the proportion of management compensation. Considering the availability and comparability of data, this paper refers to Wu Zhaohui's (2018) [11] methods to select the executive compensation concentration, that is, whether the ratio of the top three managers' compensation to the total managers' compensation is greater than the median.

In addition, based on theoretical analysis and previous research $r$, the empirical model of this paper also introduces the relevant control variables, namely Control $_{i t}$ The specific definition is shown in Table 1.

\subsection{Stationarity Test and Descriptive Statistics}

Table 2 shows the stationarity test result of all variables. All variables expect $\mathrm{rm} 2$ are stable and can be used directly in the regression. Since the growth rate of the broad money is not stable, the paper used HP Filter to smooth the data.

Table 3 shows the descriptive statistics of the main variables.

The table reports the descriptive statistics of the main research variables under the full sample. It can be seen from the table that the bankruptcy risks of 28 
Table 1. Definition of variables.

\begin{tabular}{|c|c|c|c|}
\hline & Variables & Symbol & Variable definition \\
\hline $\begin{array}{l}\text { Explained } \\
\text { variable }\end{array}$ & Bank risk-taking & RISK & Z-score \\
\hline \multirow[t]{5}{*}{$\begin{array}{l}\text { Explaining } \\
\text { variable }\end{array}$} & Managerial Optimism & OP & $\begin{array}{l}\text { If the sum of the top three managers' } \\
\text { compensation/the sum of all managers' } \\
\text { compensation over average op }=1 \text {, } \\
\text { else op }=0\end{array}$ \\
\hline & Capital adequacy & CAR & Total capital/weighted risk assets \\
\hline & Liquidity & $\mathrm{DL}$ & $\begin{array}{l}\text { Deposit-loan ratio }=\text { Sum of deposit } / \text { sum } \\
\text { of loan }\end{array}$ \\
\hline & $\begin{array}{c}\text { Provisioning coverage } \\
\text { rates }\end{array}$ & PCR & $\begin{array}{l}\text { Actual provision for loan loss/non-performing } \\
\text { loan }\end{array}$ \\
\hline & Cost-income ratio & CIR & $\begin{array}{l}\text { Business and management } \\
\text { expenses/operating income }\end{array}$ \\
\hline \multirow{6}{*}{$\begin{array}{l}\text { Control } \\
\text { variables }\end{array}$} & $\begin{array}{l}\text { Non-interest income } \\
\text { ratio }\end{array}$ & NIR & $\begin{array}{l}\text { Non-interest income ratio = non-interest } \\
\text { income/Total interest income }\end{array}$ \\
\hline & Net interest margin & NIM & $\begin{array}{l}\text { Net interest margin }=(\text { interest income }- \\
\text { interest expense)/average interest-earning } \\
\text { assets }\end{array}$ \\
\hline & Scale & LNA & LNA $=\operatorname{Ln}($ Total Assert $)$ \\
\hline & Market structure & CR5 & $\begin{array}{l}\text { Total loans of the five state-owned } \\
\text { banks/balance of loans of national } \\
\text { financial institutions }\end{array}$ \\
\hline & Macroeconomic & RGDP & GDP growth rate \\
\hline & variable & RM2 & M2 growth rate \\
\hline
\end{tabular}

Table2. Stationarity test result.

\begin{tabular}{cccccc}
\hline & $\mathrm{P}$ & $\mathrm{Z}$ & $\mathrm{L}^{*}$ & $\mathrm{Pm}$ & Result \\
\hline op & 0.0026 & 0.0003 & 0.0001 & 0.0004 & Stable \\
risk & 0 & 0 & 0 & 0 & Stable \\
$\mathrm{dl}$ & 0 & 0.5418 & 0.0214 & 0 & Stable \\
$\mathrm{pcr}$ & 0 & 0 & 0 & 0 & Stable \\
cir & 0 & 0 & 0 & 0 & Stable \\
nir & 0 & 0.7806 & 0.0064 & 0 & Stable \\
nim & 0 & 0 & 0 & 0 & Stable \\
lna & 0 & 0 & 0 & 0 & Stable \\
cr5 & 0 & 0 & 0 & 0 & Stable \\
rgdp & 0 & 0 & 0 & 0 & Stable \\
rm2 & 1 & 1 & 1 & 0.9996 & Unstable \\
\hline
\end{tabular}

listed banks range from 0.395 (Pingan Bank, 2009) to 343.1 (China Construction bank, 2013), with an average of 21.99. This shows that the difference in risk-taking between listed commercial banks varies greatly. The over-optimistic average of the dummy variable is 0.401 . 
Table 3. Descriptive statistics.

\begin{tabular}{ccccccc}
\hline Variables & mean & sd & $\min$ & $\max$ & $\mathrm{p} 50$ & $\mathrm{~N}$ \\
\hline zscore & 21.989 & 42.300 & 0.395 & 343.062 & 11.603 & 201 \\
op & 0.483 & 0.501 & 0.000 & 1.000 & 0.000 & 201 \\
ccar & 0.122 & 0.027 & 0.037 & 0.307 & 0.121 & 201 \\
dl & 0.681 & 0.080 & 0.390 & 0.920 & 0.699 & 201 \\
pcr & 2.257 & 0.894 & 0.476 & 4.996 & 2.069 & 201 \\
cir & 0.324 & 0.055 & 0.216 & 0.477 & 0.316 & 201 \\
nir & 0.193 & 0.087 & -0.016 & 0.423 & 0.185 & 201 \\
nim & 0.025 & 0.004 & 0.013 & 0.043 & 0.025 & 201 \\
lna & 9.930 & 1.465 & 6.627 & 12.472 & 10.012 & 201 \\
rgdp & 0.126 & 0.050 & 0.070 & 0.231 & 0.104 & 201 \\
rm2 & 0.146 & 0.048 & 0.082 & 0.277 & 0.136 & 201 \\
cr5 & 0.503 & 0.040 & 0.443 & 0.576 & 0.509 & 201 \\
\hline
\end{tabular}

Also, it is generally believed that when the correlation coefficient reaches 0.8 or more, there may be multiple collinearity problems. By performing correlation analysis, it can be seen that the model does not have serious multi-collinearity problems. So this paper chooses to use OLS to regress the model.

\subsection{Regression Result}

By doing Hausmann's test, Prob $>$ chi $2=0.0615$ which means we cannot reject the null hypothesis at the $5 \%$ confidence level, so this paper uses the random effects model for regression. Table 4 shows the regression result of the relationship between managerial optimism and bank risk-taking.

This paper examines the sensitivity of bank risk-taking to managerial optimism. The regression results are shown in the Table 3. It can be seen from the table, the bank's Z-value is significantly negatively correlated with management optimism at a $5 \%$ confidence level. The higher the $Z$ value, the more stable the bank, the less risk the bank will go bankrupt. Therefore, the empirical results of this paper show that the more optimistic of management of commercial banks are, the higher risk the banks take. Hypothesis is confirmed.

In addition, in terms of the influencing factors of bank risk exposure, the empirical results of the table also show that the core capital adequacy ratio will reduce the bank's risk exposure. Capital adequacy can reduce the willingness of banks to take risks through the value of the concession, thereby reducing risk. At the same time, as the loan-to-deposit ratio (DL) increases, bank liquidity reserves decrease and risks increase. The larger the bank, the higher the probability of receiving government support in times of crisis and the lower the risk of bankruptcy. In addition, the more adequate the money supply (RM2), the increased market liquidity, and the lower the bank risk. 
Table 4. Regression result.

\begin{tabular}{cccc}
\hline zscore & Coef. & Std. Err. & p-value \\
\hline op & $-13.69173^{* *}$ & 6.49334 & 0.035 \\
ccar & 0.75031 & 1.30678 & 0.566 \\
dl & -0.12272 & 0.4155821 & 0.768 \\
pcr & $0.06455^{*}$ & 0.037215 & 0.083 \\
nim & $15.66408^{*}$ & 9.206046 & 0.089 \\
nir & 0.15019 & 0.5543189 & 0.786 \\
cir & -0.21879 & 0.6899699 & 0.751 \\
lna & $5.425803^{* *}$ & 2.686436 & 0.043 \\
rgdp & $-155.0694^{* *}$ & 76.21006 & 0.042 \\
rm2 & -92.78595 & 84.26688 & 0.271 \\
cr5 & 138.5046 & 92.70359 & 0.135 \\
cons & $-112.4224^{*}$ & 64.17748 & 0.080 \\
R-sq & & & 0.1351 \\
\hline
\end{tabular}

$\mathrm{t}$-value in parentheses, ${ }^{*}, * *, * *$ indicate the level of significance of $10 \%, 5 \%$ and $1 \%$, respectively.

\subsection{Robustness Test}

In order to test the robustness of the research, this paper also uses Zhang Cheng et al.'s (2014) [12] method calculate management optimism. If the bank's loan growth rate is above $30 \%$ of the ranking, OP equals to 1 , indicating optimism. If the ranking is below $70 \%$, OP equals to -1 , standing for pessimism. And for the rest of banks, OP is defined as 0 . The regression results of managerial optimism and bank risk-taking calculated by this method are not significantly different from the regression results above. In addition, this paper uses the weighted risk assets to account for the proportion of total assets to represent the bank's risk-taking, and there is no significant difference in the regression results either. Therefore, the research results in this paper can be considered to be robust.

\subsection{Conclusions}

By the regression analysis of the annual data of 28 listed banks in China from 2006 to 2017, we empirically analyzed the impact of management optimism on bank risk exposure. The results show that the excessive optimism of the management of listed banks in China will have a significant impact on their risk exposure. Excessive optimism in management can lead to an increase in bank bankruptcy risk.

Since a large number of city commercial banks and rural commercial banks are not listed, their financial data are difficult to obtain or there are a lot of missing. This paper only studies the relationship between the managerial optimism and risk-taking of the listed banks. But for small banks, the lack of supervision makes the management of these banks more likely to be overly optimistic. 
In the future, if the banks in the sample can be enriched, the research will be more convincing.

\section{Policy Suggestions}

Based on the above conclusions, combined with the actual development of China's banking industry, this paper proposes the following policy recommendations:

First, we should continue to reform the management incentive model. For example, we can prevent the management from overconfidence by limiting the management's holdings of shares and setting the highest salary. At the same time, the owner may employ an external independent director or supervisor to supervise the management.

Second, the core capital adequacy ratio, deposit-to-deposit ratio, net interest margin, net interest spread, asset size and other factors and the degree of optimism of bank managers are intertwined and interact, which will lead to more complex risk-taking relationships. Therefore, when formulating relevant policies, the authorities must not only consider the direct effects of individual policies, but also consider the impact of these policies on managers' optimism and consider the effect of such indirect policies.

\section{Conflicts of Interest}

The author declares no conflicts of interest regarding the publication of this paper.

\section{References}

[1] Gorton, G. and Rosen, R. (1995) Corporate Control, Portfolio Choice and the Decline of Banking. Journal of Finance, 50, 1377-1420. https://doi.org/10.1111/j.1540-6261.1995.tb05183.x

[2] Anderson, R.C. and Fraser, D.R. (2000) Corporate Control, Bank Risk Taking and the Health of the Banking Industry. Journal of Banking and Finance, 24, 1383-1398. https://doi.org/10.1016/S0378-4266(99)00088-6

[3] Zhuang, Y.Z. and Jing, Y.S. (2013) Corporate Governance and Bank Risk-Taking Behavior: Based on the Research of Listed Commercial Banks of China. Finance and Management, 27, 34-38.

[4] Xu, X. and Cheng, C. (2016) The Empirical Analysis of Internal and External Difference in Executive Compensation Incentive and Bank Risk-Taking. Zhejiang Finance, 2, 52-59.

[5] Bao, H.L. (2018) Study on the Relationship among Top Management Team Heterogeneity, Risk-Taking and Bank Efficiency China. Anhui University, Hefei.

[6] Kim, J.-B., Wang, Z. and Zhang, L.D. (2016) CEO Overconfidence and Stock Price Crash Risk. Social Science Electronic Publishing, 33, 1720-1749. https://doi.org/10.1111/1911-3846.12217

[7] Adam, T.R., Fernando, C.S. and Golubeva, E. (2015) Managerial Overconfidence and Corporate Risk Management. Journal of Banking \& Finance, 60, 195-208. https://doi.org/10.1016/j.jbankfin.2015.07.013 
[8] Wang, X. (2015) An Empirical Analysis of the Determinants of Multinational Banks Entering. China Journal of Finance, 8, 63-71.

[9] Xu, J. (2018) Is Managerial Overconfidence Associated with Bank Risk? Communication of Finance and Accounting, 27, 82-85.

[10] Wang, X., Zhang, C. and Zhao, J. (2015) Managerial Optimism and Bank Risk Taking. Guizhou Social Sciences, 12, 149-154.

[11] Wu, Z.H. (2018) Research on the Influence of CEO Overconfidence on Loan Loss Provisioning. Hunan University, Changsha.

[12] Zhang, C., Lu, M. and Sang, X. (2014) Investor Sentiment, Managerial Optimism and Bank Risk Taking. Journal of Shanxi Finance and Economics University, 36, 48-57. 